\title{
Natural versus anthropogenic sources of channel sand and fine gravel following integrated logging in the Letts Creek catchment, NSW
}

\author{
Wayne D. Erskine ${ }^{1}$
}

\author{
${ }^{1}$ Sustainable Use of Coasts and Catchments, School of Environmental and Life Sciences, \\ University of Newcastle - Ourimbah Campus, PO Box 127, Ourimbah, NSW 2258, Australia \\ Email: Wayne.Erskine@newcastle.edu.au
}

Revised manuscript received 12 May 2009

\section{Summary}

Integrated logging immediately before a large storm in February 1992 caused extensive erosion of a feeder road in compartment $588 / 2$ of Yambulla State Forest that allegedly supplied large amounts of sand and fine gravel to the downstream river channel where pools were supposedly infilled. However, most sediment eroded on the feeder road was actually stored on slopes and in filter strips before reaching channels. Subsequent soil conservation works rehabilitated the worst-eroded areas and they are still functioning effectively today. There is no direct connection of sand and fine gravel between the general harvest area and downstream channels because of many intervening sediment discontinuities, such as ponds, drainage lines, filter strips and floodouts ${ }^{1}$. The catastrophic flood of February 1971 was the largest for at least the last $50 \mathrm{y}$ in the Towamba catchment and caused substantial widening of lower Letts Creek and Wog Wog River. It also reorganised channel-spanning boulder steps on upper Letts Creek and a tributary in and immediately downstream of compartment $588 / 2$, and may have caused gully erosion on the tributary of Letts Creek. Bank erosion supplied the sand and fine gravel in the river bed of these headwater channels. A cluster of large floods between 1988 and 1992 exacerbated bank erosion in the two channels draining the logged compartment and infilled pools.

Keywords: floods; stream flow; erosion; sediment; sediment yield; geological sedimentation; storage; banks

\section{Introduction}

Megahan's (1972) well-known paper in the Journal of Forestry emphasised that although harvesting, especially skidding and roading, can accelerate erosion and sedimentation, there are guidelines that should be followed to minimise these problems. Sediment sources, storages, sinks and fluxes are complex processes that generate much debate worldwide, especially in relation to forestry activities (Wolman 1977). Judge R.H. Kroninger, in a case over logging in a Californian redwood forest, ruled that:

While numerous expert witnesses in the field of geology, forestry, engineering and biology were presented, their conclusions and the

\footnotetext{
${ }^{1}$ Floodouts are poorly drained, depositional areas without integrated channels.
}

opinions they derived from them are hopelessly irreconcilable on such critical questions as how much and how far solid particles will be moved by any given flow of surface water. They were able to agree only that sediment will not be transported upstream.

(Wolman 1977 p. 50). Similar irreconcilable differences about the impacts of forestry activities are often publicised in the Australian popular press. Integrated logging — the joint harvesting of sawlogs and pulpwood - has been conducted in native forests near Eden, NSW, since 1969 and has generated controversy over linkages between on-site accelerated soil erosion and off-site stream sedimentation (Routley and Routley 1975; Burgess 1987; Olive and Rieger 1988; Erskine 1992; Erskine and Harris 2004). While significant research has been directed at determining how integrated logging affects soil erosion rates and sediment supply to rivers, logged compartments are certainly not significant sources of sand and fine gravel for channels further down slope (e.g. Mackay et al. 1985; Burgess 1987; Olley et al. 1996; Croke et al. 1997, 1999a,b,c, 2001; Wallbrink and Croke 2002; Wallbrink et al. 1997, 2002; Erskine and Harris 2004).

Nevertheless, integrated logging of compartment 588, coupe 2 (Cpt 588/2) in Yambulla State Forest in late January 1992 (Fig. 1) allegedly caused soil erosion and consequent sand supply to channels in upper Letts Creek, Towamba River catchment, NSW. Critics have alleged that an intense storm on 11 February 1992 caused such widespread soil erosion in Cpt 588/2 that downstream channels were oversupplied with sand and fine gravel and, as a result, pools of various types were infilled with sand. Pools are a type of aquatic habitat or channel unit that Thompson et al. (2006) defined as homogeneous morphological features displaying similar grain size, flow depth, current velocity and slope. Each channel unit has been shown to exhibit statistically significantly different physical characteristics (Peterson and Rabeni 2001a) and, in perennial rivers, can be associated with unit-specific assemblages of fish species (Peterson and Rabeni 2001b). The two channels in Cpt 588/2 allegedly affected by sedimentation are upper Letts Creek and an unnamed left-bank tributary (Fig. 2). Sand and fine gravel supposedly derived from the general harvest area completely smothered downstream pools and riffles. Long sediment residence times in Letts Creek mean that the sediment delivered to the channels by the 1992 storm is still present today. Furthermore, there has not been another event since 1992 that was capable of entraining a significant proportion of the sand and fine 
gravel. Channel banks are supposedly stable, showing no signs of recent bank collapse. In addition, the bank sediment is different in grain size from the channel bed material and allegedly was not an active sediment source.

The purposes of work described in this paper were to determine the nature of recent sedimentation in upper Letts Creek and the most important sources of sand and fine gravel to Letts Creek and the unnamed left-bank tributary.

It is difficult to resolve such an issue $16 \mathrm{y}$ after it arose. Nevertheless, Forests NSW records, various unpublished accounts, field inspections and measurements, laboratory analyses of sediment samples, repeated vertical air photographs, rainfall and flood

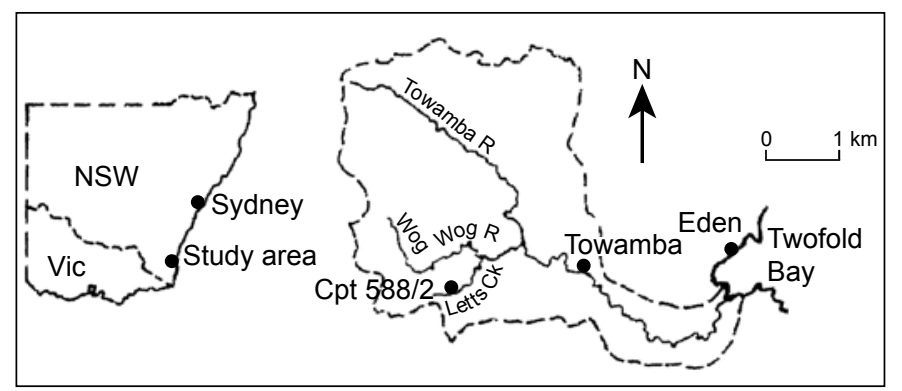

Figure 1. Towamba River catchment showing Letts Creek and the location of Cpt 588/2 in Yambulla State Forest

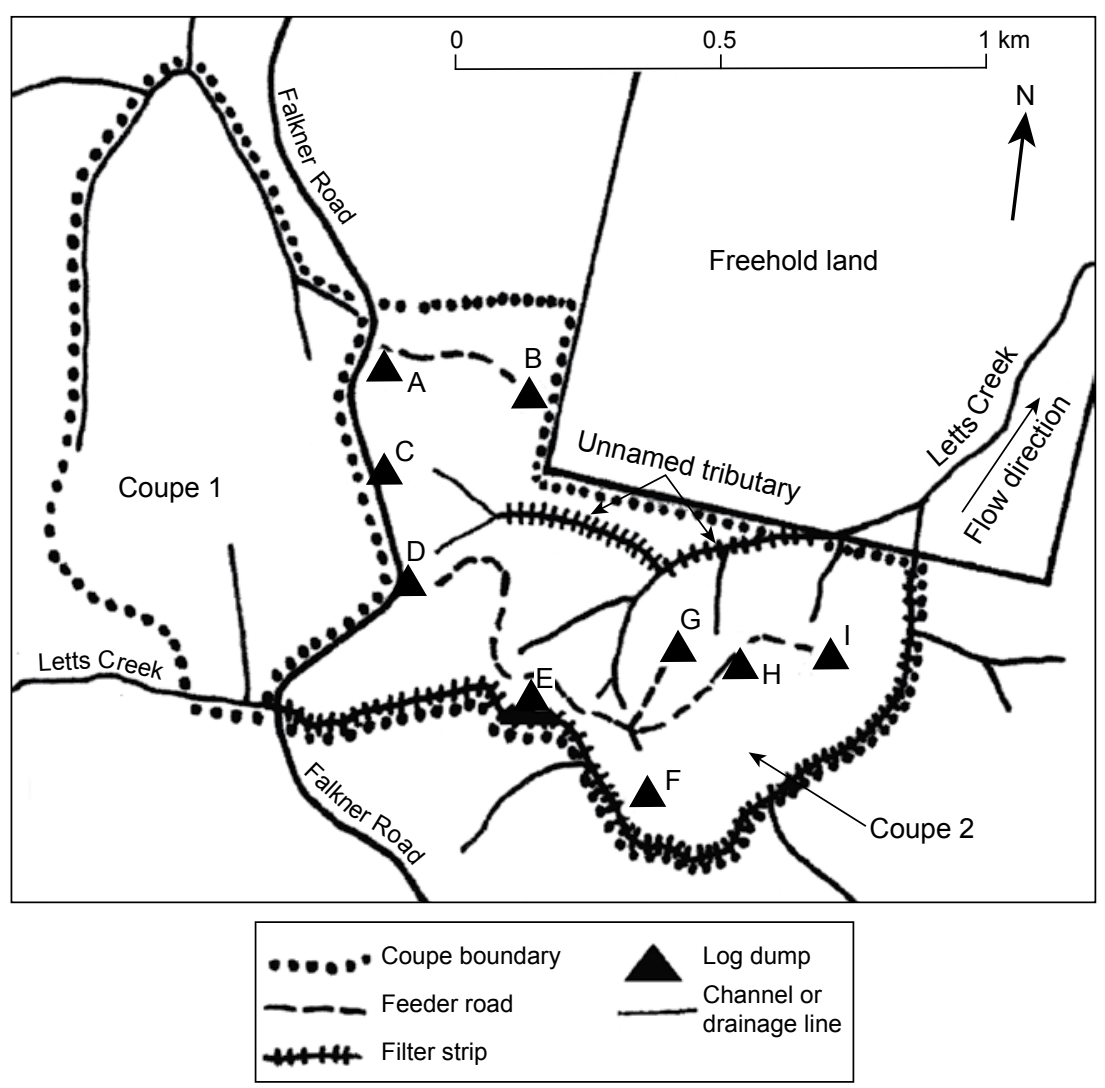

Figure 2. Part of harvest plan map for Cpt 588/2 of Yambulla State Forest finalised in January 1992, showing neighbouring freehold land and the two channels that are discussed in this paper records for the Towamba catchment, published results on soil erosion in nearby harvested compartments and the effectiveness of management practices in reducing soil erosion and sediment supply to channels in similar timber production forests have been used to achieve the above goals.

This work was commissioned by Forests NSW as an independent assessment of sand and fine gravel sources in Cpt 588/2, Yambulla State Forest. The Letts Creek catchment is briefly described below before the history of integrated logging in Cpt 588/2 is outlined. Then the current channel units in Letts Creek and the unnamed left-bank tributary in Cpt 588/2, and their mode of formation, are presented. The relevant intense large storms and floods that have occurred in the Letts Creek catchment over the last $40 \mathrm{y}$ are then identified. Lastly, the actual effects of integrated logging in $\mathrm{Cpt}$ $588 / 2$ on soil erosion and on the sand and fine gravel supply to channels are deduced.

\section{Letts Creek catchment}

Letts Creek drains a total catchment area of $24.55 \mathrm{~km}^{2}$ and is a tributary of the Wog Wog River which flows into the Towamba River, which, in turn, flows into Twofold Bay south of Eden (Fig. 1). The catchment areas of Letts Creek and the unnamed left-bank tributary in Yambulla State Forest are $1.71 \mathrm{~km}^{2}$ and $0.51 \mathrm{~km}^{2}$, respectively (Fig. 2). Their respective catchment areas at their confluence in downstream freehold land (Fig. 2) are 1.73 and $0.86 \mathrm{~km}^{2}$. Bed slopes on both channels are very steep, always exceeding $15.4 \mathrm{~m} \mathrm{~km}^{-1}$.

Mean annual rainfall over the Towamba catchment is $813 \mathrm{~mm}$, of which $26 \%(211 \mathrm{~mm})$ is converted to runoff (Anon. 1968). Monthly rainfall between December and April is slightly higher than between May and November (Anon. 1968). Thompson et al. (2008) found that streams draining catchments of $<2 \mathrm{~km}^{2}$ in the Towamba basin are ephemeral, a result consistent with observations during the present study.

Most of the Letts Creek catchment is underlain by Ordovician Adaminaby Group sediments and metasediments and by two formations of the Devonian Bega Batholith, namely Pericoe Adamellite and Kameruka Granodiorite (Lewis and Glen 1995). Pericoe Adamellite outcrops in Cpt 588/2 and most of the upper reaches of Letts Creek (Lewis et al. 1995). The Adaminaby Group outcrops in the headwaters of Letts Creek as well as on the western side of the catchment. Kameruka Granodiorite outcrops only in the lower catchment (Lewis and Glen 1995).

Most of Cpt $588 / 2$ before harvesting was dominated by mature to overmature forest type 157 , yellow stringybark-gum, with the remainder either forest type 112, silvertop ash, or forest type 114, silvertop ash-stringybark (Anon. 1989). All future sawlog trees capable of net merchantable increment were retained for a subsequent cutting cycle. 


\section{History of integrated logging and soil conservation works in compartment $588 / 2$ of Yambulla State Forest}

Integrated logging involves harvesting alternate coupes that are variable in size but average about 50 ha. Adjacent coupes are harvested at intervals of at least a decade. Cpt 588/2 was the first of the two coupes to be harvested. Sleeper-cutters had logged the coupe in the past. The harvesting plan for Cpt 588/2 was signed on 22 January 1992 and the associated map is shown in Figure 2. Soil erosion hazard was assessed as high and this meant shorter cross-drain spacing on snig tracks than in less erodible compartments. Logging operations were supposed to conform to both the 'Code of Logging Practice, Native Forest Areas, Eden, Bombala and Bega Districts' (Anon. 1990) and the 'Erosion Mitigation Conditions for Logging in Eden Forestry Region' (Anon. 1985). Felling and snigging were excluded from filter strips, which were a minimum of $20 \mathrm{~m}$ wide for side slopes less than $18^{\circ}$ and a minimum of $40 \mathrm{~m}$ wide for side slopes greater than $18^{\circ}$.

The first complaint of poor roading practices was on 26 January 1992. Nevertheless, there was only a short time between completion of the harvest plan and the storm of 11 February 1992 so that the coupe had not been completely logged when the storm occurred. A site inspection was arranged on 4 March 1992 and the Soil Conservation Service provided written advice on the nature, location and severity of soil erosion as well as on suggested remedial works. Critics were annoyed by the contents of this advice, which did not identify the logged area as the main source of sand and fine gravel to downstream channels.

The Soil Conservation Service concluded that:

- The February 1992 storm did deposit sand and fine gravel in Letts Creek.

- A specific pool on Letts Creek immediately downstream of Cpt 588/2 was infilled with sand.

- Woody debris was present in Letts Creek and had contributed to bank erosion. The logging operation in Cpt 588/2 was not identified as the upstream sediment source but natural stream bank erosion, which continually provides a base level of sedimentation, was.

- Severe soil erosion did occur in parts of the coupe during the February 1992 storm.

- Road drainage was the main contributor to soil erosion. In particular, construction of a feeder road between log dumps D and E (Fig. 2) had caused erosion because of steep road grades and excessive cross-fall. Furthermore, soil erosion had been caused by the concentration by snig tracks of overland flow in the drainage line to the immediate north of log dump E, by ridgetop road drainage being diverted onto logged side-slopes, and by log roads being routed across side-slopes.

- A sediment control dam below log dump E (Fig. 2), diversion banks to direct overland flow from the logged area and road to the dam, silt fencing in upslope drainage lines to restrict drainage line erosion, and greater retention of forest were recommended to control sediment from the feeder road.

Recommended rehabilitation works were implemented by 3 June 1992 (Fig. 3). All disturbed non-road pavement areas

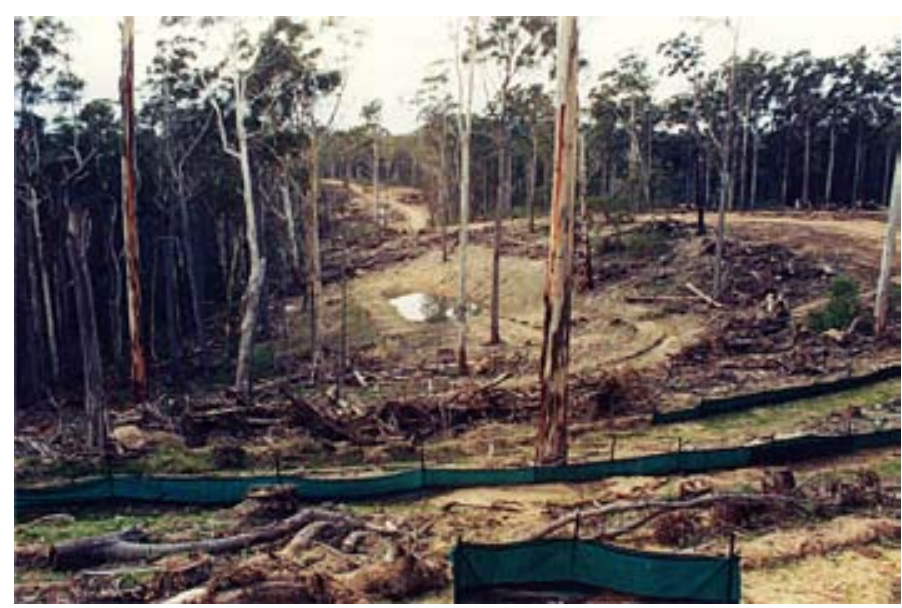

Figure 3. Final rehabilitation of the feeder road, showing the sedimentation pond, silt fences and diversion banks. Photograph by the Soil Conservation Service, 1993.

were revegetated by the Soil Conservation Service using spray seeding and hydromulching. Sown grasses were still present on parts of the rehabilitated area in March 2004. Maintenance work was undertaken because two generations of fabric fences are present. Furthermore, the sedimentation pond had not been infilled with sediment by 2004 when it contained no more than $6.8 \mathrm{~m}^{3}$ of sediment (see below). The total pond capacity in 2004 was at least two orders of magnitude greater than the retained sediment volume.

After the February 1992 storm, three dockets were issued for breaches of regulatory conditions. Other minor examples of noncompliance were documented in the compartment working file. Harvesting finished at the end of March 1993 and the post-harvest burn was conducted between 19 and 22 July 1993. Figure 4 shows Cpt 588/2 before and after integrated logging and the post-harvest burn. Undisturbed filter strips are evident along the two channels. Two indices of the intensity of integrated logging in Cpt 588/2 were derived from Forests NSW harvesting files, namely specific sawlog yield (volume per unit of net harvest area) and specific pulpwood yield (mass per unit of net harvest area). From the net harvest area of $74.3 \mathrm{ha}$, a specific sawlog yield of $13.8 \mathrm{~m}^{3} \mathrm{ha}^{-1}$ and a specific pulpwood yield of $170.8 \mathrm{t} \mathrm{ha}^{-1}$ were obtained. These yields were typical for the upper Letts Creek catchment at that time.

\section{Channel units in the upper Letts Creek catchment in Cpt 588/2}

The results of my study of the two channels in Cpt 588/2 (Fig. 2), the unnamed left-bank tributary and Letts Creek, will be discussed separately.

\section{Unnamed left-bank tributary}

In 2004, when my field work was conducted, this tributary exhibited two reaches below an upper drainage line, which, in downstream sequence, were an upstream gullied reach and a downstream bedrock-confined reach. 

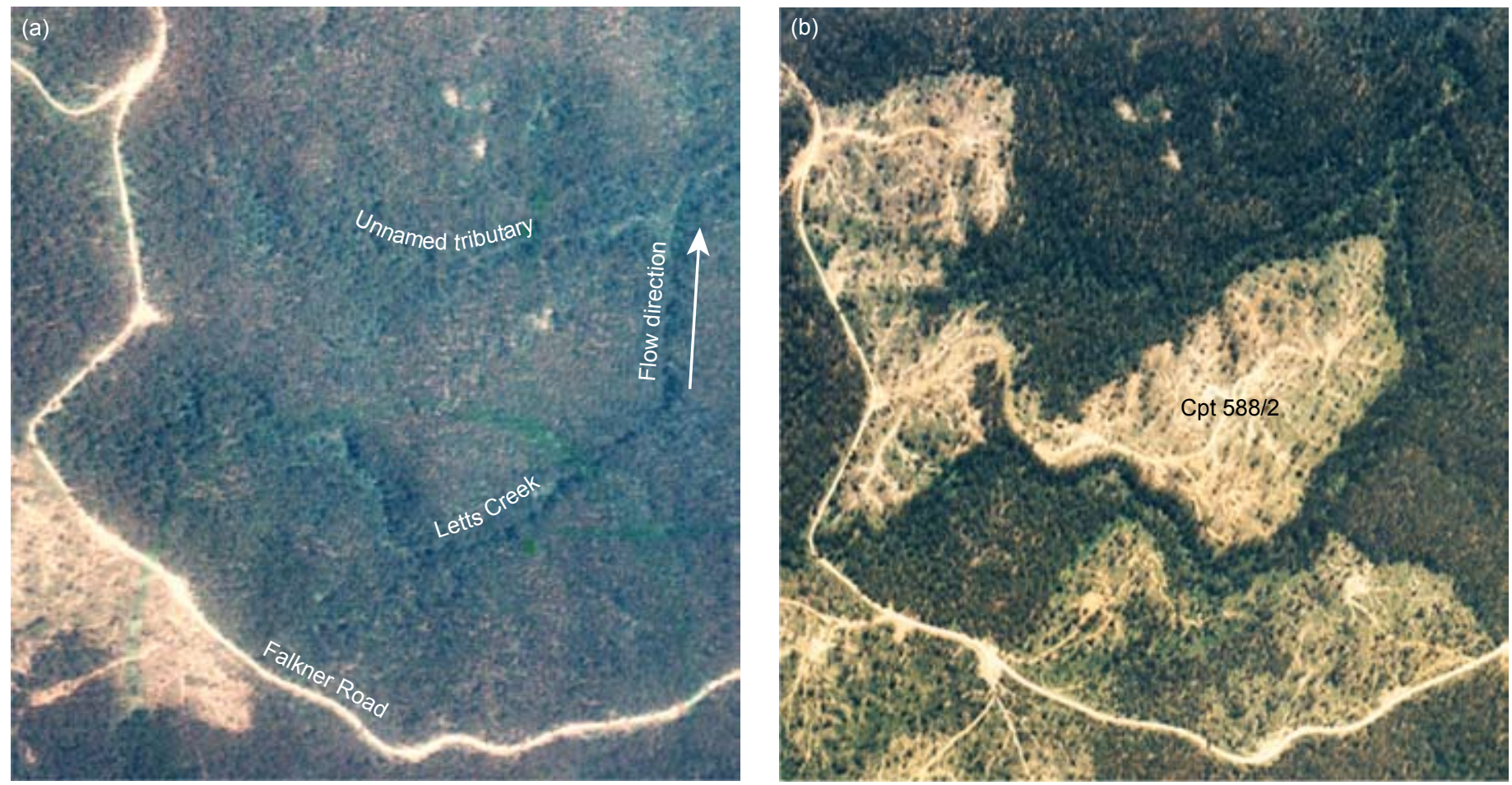

Figure 4. Vertical air photographs of Cpt 588/2 in (a) November 1989 before integrated logging and in (b) November 1993 after completion of integrated logging and post-harvest burn

\section{Upstream gullied reach}

The upstream gullied reach consisted of two discontinuous gullies, each characterised by:

- an upper incised zone with a deep channel (up to $3 \mathrm{~m}$ ) and with multiple headcuts. Bedrock was frequently exposed in the gully bed and restricted the depth of incision

- a middle section where gully depth rapidly decreased downstream

- a downstream depositional zone where there was essentially no channel and hence gully-derived sediment was deposited over the whole valley floor in a floodout (Melville and Erskine 1986).

Floodouts refer to poorly drained areas without integrated channels and are characterised by rapid deposition due to an abrupt decrease in specific stream power at the upstream limit of the floodout (Melville and Erskine 1986). They are very efficient sediment traps. Melville and Erskine (1986) found, from a detailed sediment budget, that floodouts can retain $53 \%$ of the total eroded sediment from the upstream gully. When the sediment stored in the gully upstream of the floodout was included, the total stored sediment in the gully was equal to $90 \%$ of the total eroded sediment volume. Neil and Fogarty (1991) found that a floodout on a discontinuous gully on the Southern Tablelands trapped $60 \%$ of the eroded sediment. The floodouts on the unnamed tributary also trapped a large proportion of the transported sediment. A deep pit excavated in the lower floodout revealed a vertically stacked sequence of stratified flood deposits of coarse sandy granule gravel (texture classification of Folk (1980)) up to $0.13 \mathrm{~m}$ thick interbedded with organic-enriched muddy sand units up to $0.35 \mathrm{~m}$ thick. Five gravel layers were present in the pit: these are major flood deposits. The muddy sands represent the cumulative deposition of a number of smaller floods. As the pit did not expose the complete depth of floodout deposits, more floods may be recorded below the base of the pit. Hydrologic analyses reported below suggest that only three gravel-transporting events have occurred since January 1992, and hence the gully predates integrated logging. Furthermore, eucalypt trees whose roots have been exposed by gully erosion have large diameters $(>0.5 \mathrm{~m})$, indicating that the gullies are older than $30 \mathrm{y}$.

The two important conclusions to be drawn from the above are that the gullies predate the harvesting of Cpt 588/2 and that floodouts have trapped a large but unspecified proportion of the sediment transported through the gully. Furthermore Prosser and Soufi (1998), who investigated gully initiation in neighbouring pine plantations, concluded that gully erosion was caused during their study period (1983-1991) only by the 21 April 1988 storm when $206.4 \mathrm{~mm}$ were recorded at Towamba (see below). Such a large storm had to have occurred within 12 mo of soil ripping or else soil strength recovered, resisting erosion by overland flows. The February 1992 storm (124.8 mm) was much smaller than the April 1988 storm, and the valley floor in Cpt 588/2 had not been disturbed by ripping and hence had greater soil strength than the ripped areas in neighbouring pine plantations. Therefore, the event that initiated gully erosion in Cpt 588/2 would have been even greater than the 21 April 1988 storm and the only two such events to have been recorded at Towamba were in February 1971 and June 1978 (see below), a long time before February 1992. 


\section{Downstream bedrock-confined reach}

A continuous channel to Letts Creek is present downstream of the lower floodout. The degree of bedrock confinement varies from short gorge sections to longer sections where pocket floodplains have developed. The main channel units included cascades; boulder, log, root and bedrock steps with step pools; and rapids in the steeper sections (Grant et al. 1990; Thompson et al. 2006) and, less commonly, riffles and pools in the flatter sections (Keller 1971; Lisle 1979; Thompson et al. 2006). A mixture of sand and fine gravel infills step pools impounded by interlocked boulders, logs and roots which form the steps. The sand and fine gravel overpasses the immobile boulders, logs and roots which form the bed framework. It is the overpassing mixture of sand and fine gravel that has concerned critics of forestry. Where there are alluvial banks, they have been eroded, being steep, unvegetated and irregular in plan. The flatter reaches also have a high loading of large wood which is defined here as wood of any length greater than $0.1 \mathrm{~m}$ in diameter. This wood has caused occasional bank erosion by flow diversion but its effects on increasing channel roughness, stabilising bed steps and protecting banks far outweigh its negative effects.

High-energy boulder steps and transversely aligned boulders in cascades are deposited by very large, infrequent floods with return periods of about 1:100 y, as demonstrated by Grant et al. (1990). When such events occur, the structure of the bed is completely reorganised and bank erosion certainly occurs (Thompson et al. 2006, 2008). Riffles and pools are much lower energy channel units, and are mobile and are maintained by pool scour and simultaneous riffle deposition by moderate floods of frequent occurrence, such as 1:2 y (Keller 1971; Lisle 1979; Thompson et al. 2006, 2008). During even smaller floods, pools infill with sediment and riffles scour (Keller 1971; Lisle 1979). Therefore, different channel units in the bedrock-confined reach are mobile under different-sized floods. As outlined below, the last flood that may have transported and reorganised boulders was in February 1971 (Thompson et al. 2008). The February 1992 flood, however, would have shaped the flatter sections of channel with riffle-pool sequences but not the high-energy channel units.

\section{Upper Letts Creek}

Below Falkner Road, the slope of Letts Creek steepens and a range of high-energy channel units are present. These include bedrock and large boulder steps and step pools, boulder and rock dams and cascades (Grant et al. 1990; Thompson et al. 2006, 2008). Again there was a surficial veneer of sand and fine gravel that overpassed the boulders and bedrock forming the bed framework. Sand and fine gravel were directly supplied to the channel by landslips, bank erosion and bed degradation.

Figure 5 shows grain size distributions for six sediment samples. Bulk bed samples were obtained of the overpassing mixture of sand and fine gravel from the downstream bedrock-confined reach of the left-bank tributary (two samples) and Letts Creek (one sample). Bulk samples were also obtained of bank sediment from the downstream bedrock-confined reach of the left-bank tributary (one sample) and of sediment from the sedimentation pond (two samples - see below). They were analysed for grain size by the NSW Department of Lands laboratory at Scone. The three bed samples are similar to each other and to the pond delta unit (discussed below), and contained no sediment coarser than $16 \mathrm{~mm}$. These sediments correspond to the fine sediment mode of granite catchments of Thompson et al. (2006) and do not represent the bed framework that forms the boulder steps. The bank sediment is a mixture of the mud pond unit in the sedimentation pond (discussed below), and the fine mode of channel bed material. Preferential removal of fine sediment and organic matter from the bank sediment will produce the fine mode of the bed material because the bank grain size range is exactly the same as the fine mode for the bed. Therefore, the comment that the bed sediment cannot be produced from the bank sediment is incorrect, at least for the fine sediment mode. Furthermore, it must be emphasised that it is only the downstream bedrock-confined reach of the left-bank tributary that is directly connected to Letts Creek and hence can supply sand and fine gravel.

\section{Effects of large floods on channels in the Towamba catchment}

The purpose of this section is to establish the magnitude and frequency of large, infrequent rainstorms and floods in the Towamba River catchment.

The closest rainfall station to $\mathrm{Cpt} 588 / 2$ with a record length adequate for frequency analysis is Towamba (Rosebank, Bureau of Meteorology Station No. 69110; period of record 1971-2001). It is $5 \mathrm{~km}$ east of the Letts Creek catchment. The closest river gauging station with a record length adequate for flood frequency analysis is the Towamba River at Towamba (Department of Water and Energy Station No. 220004; catchment area $764 \mathrm{~km}^{2}$ ). The annual maximum series of 1-, 2- and 3-day duration rainfall depths at Towamba for the period 1972-2001 were extracted

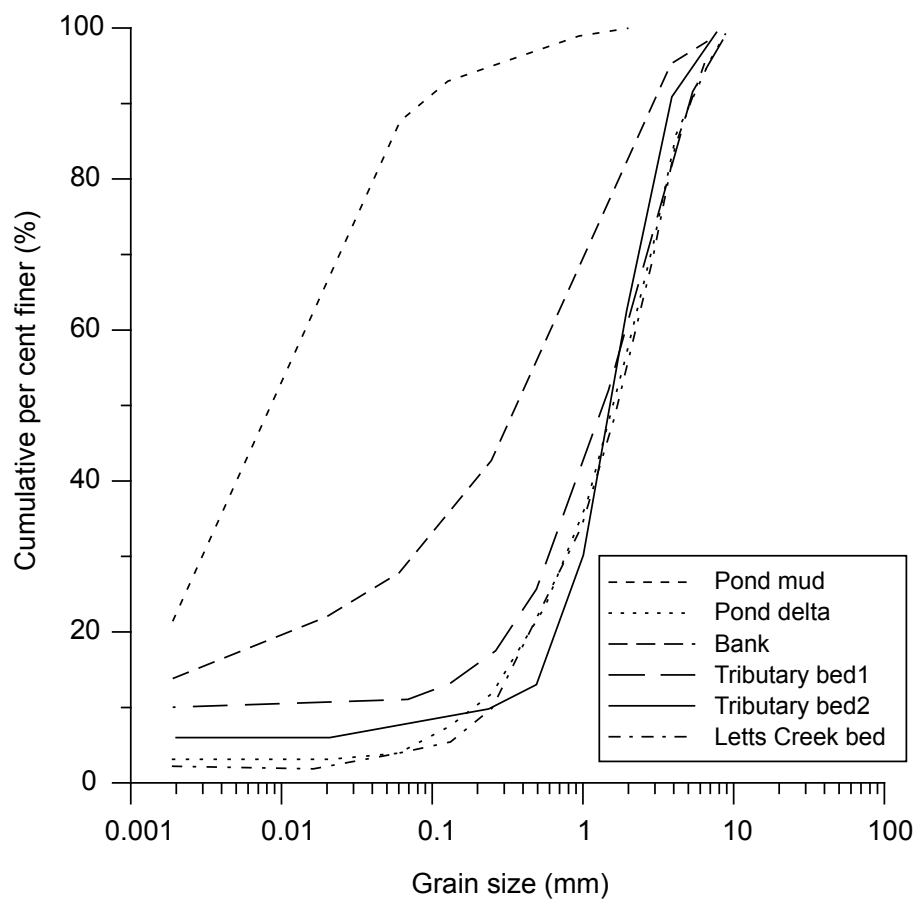

Figure 5. Grain size distributions of various sediment populations in Cpt 588/2 
from the daily rainfall record. The February 1971 storm was a very large event on the South Coast of NSW (Bishop 1973; Anon. 1976; Thompson et al. 2008) and in neighbouring East Gippsland, Victoria (Erskine 1993, 1999; Erskine and Saynor 1996). Therefore, rainfall for the station 'Near Towamba' in Anon. (1976) for the February 1971 storm was added to the above data at Towamba to ensure that the largest event in the last $50 \mathrm{y}$ was included. An annual maximum flood series was also extracted for the Towamba River at Towamba. The method of Pilgrim and Doran (1987) was used to fit a log Pearson Type III distribution by the method of moments.

The 6-8 February 1971 storm was the largest on record (daily maximum of $252.5 \mathrm{~mm}$; return period of $71 \mathrm{y}$ ) but quickly followed a large storm between 29 January and 2 February 1971 (Anon. 1976; Erskine 1993). Furthermore, there was also an earlier but significant flood in December 1970 (Bishop 1973). There was marked temporal clustering of large storms during two time periods. Eight events with daily rainfall between 101.4 and $252.5 \mathrm{~mm}$ were recorded between February 1971 and June 1978, including the two largest on record. Three of these events occurred in four months (March to June) in 1978. Another six events with daily rainfall between 101 and $206.4 \mathrm{~mm}$ were recorded between April 1988 and February 1992, including two of the five largest. Four events occurred in 13 mo between April 1988 and April 1989. Such temporal clustering increases the erosional effects of rainstorms because of the short time between successive events during which soil stabilisation by vegetative growth and litter fall can occur.

The peak discharge of the February 1971 flood at Towamba was 11.6 times greater than the mean annual flood and hence is a catastrophic flood (i.e. peak discharge $>10$ times the mean annual flood), according to the definition of Erskine (1993, 1996, 1999; Erskine and Saynor 1996). Such events have caused large-scale channel erosion (Erskine 1993, 1996, 1999; Erskine and Saynor 1996; Erskine and Warner 1999). Many rivers in southern NSW recorded their highest historical flood in February 1971 (Anon. 1976). The June 1978 flood was the second largest and was 9 times greater than the mean annual flood. The remaining floods were less than 5.9 times greater than the mean annual flood. There was also a marked temporal clustering of large floods in two time periods, similar to those for rainfall. A series of large floods in a short time-span has caused large-scale channel erosion on many sand-bed streams in south-eastern Australia (Henry 1977; Erskine 1996; Erskine and Warner 1999).

Rainfall and flood frequency estimates of the February 1992 storm were very different to those described above (2.2-4.2 y for 1 - to 3 -day rainfall versus $7.4 \mathrm{y}$ for peak discharge). Such discrepancies between rainfall and flood estimates are commonly recorded (Newson 1980) and may be caused by spatial variations in storm intensity. Nevertheless, the February 1992 storm was not one of the larger events for the Towamba catchment.

Sequential vertical air photographs show flood effects on channels in the Towamba catchment. As the forest canopy of reserved filter strips obscured channels in Cpt 588/2 (Fig. 4), it was not possible to determine flood effects from air photographs. Wider channels not totally obscured by riparian vegetation were investigated. Figure 6 shows paired air photographs of lower Letts Creek and the Wog Wog River in July 1962 and March 1971. Both channels were greatly enlarged by the February 1971 flood and the sediment generated was stored in the river bed as a sand slug (Erskine 1993). Figure 7 shows the Wog Wog River further upstream in July 1962, March 1971 and November 1993. While the same impacts of the 1971 flood are apparent, by 1993 bedrock was exposed in the river bed in many locations, indicating that some of the stored sediment deposited by the 1971 flood had been removed by 1993 . Thompson et al. (2008) concluded that large floods in the Towamba catchment produced high specific stream power due to bedrock-confinement. Bank erosion occurs during such events (Thompson et al. 2008). Figures 6 and 7 suggest that large-scale erosion was highly likely during the February 1971 flood in Cpt 588/2. Furthermore, the flood magnitude required to exceed a channel stability threshold is much greater than the February 1992 flood which had a peak discharge at Towamba of only $48 \%$ of that in 1971 .

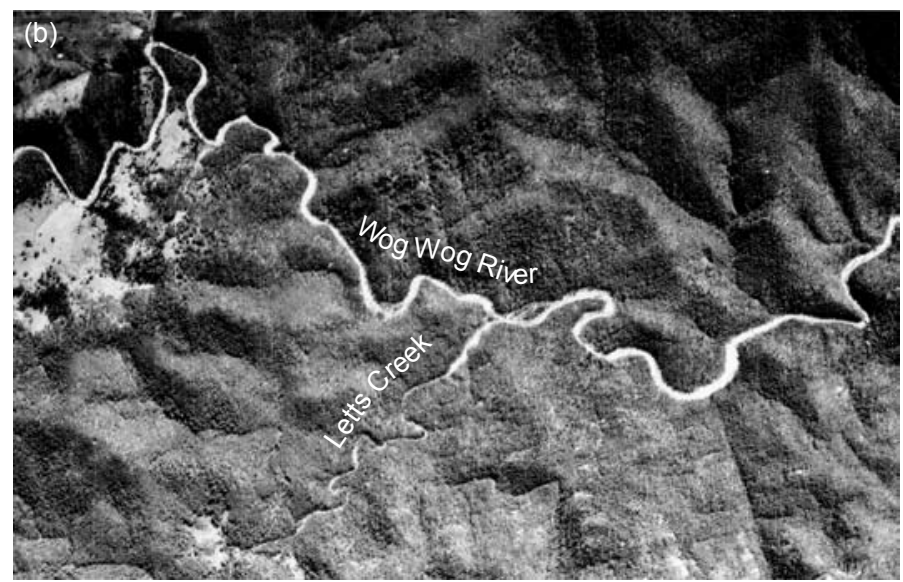

Figure 6. Vertical air photographs of Letts Creek and Wog Wog River in (a) July 1962 and (b) March 1971, showing substantial erosion and channel widening by the February 1971 flood 

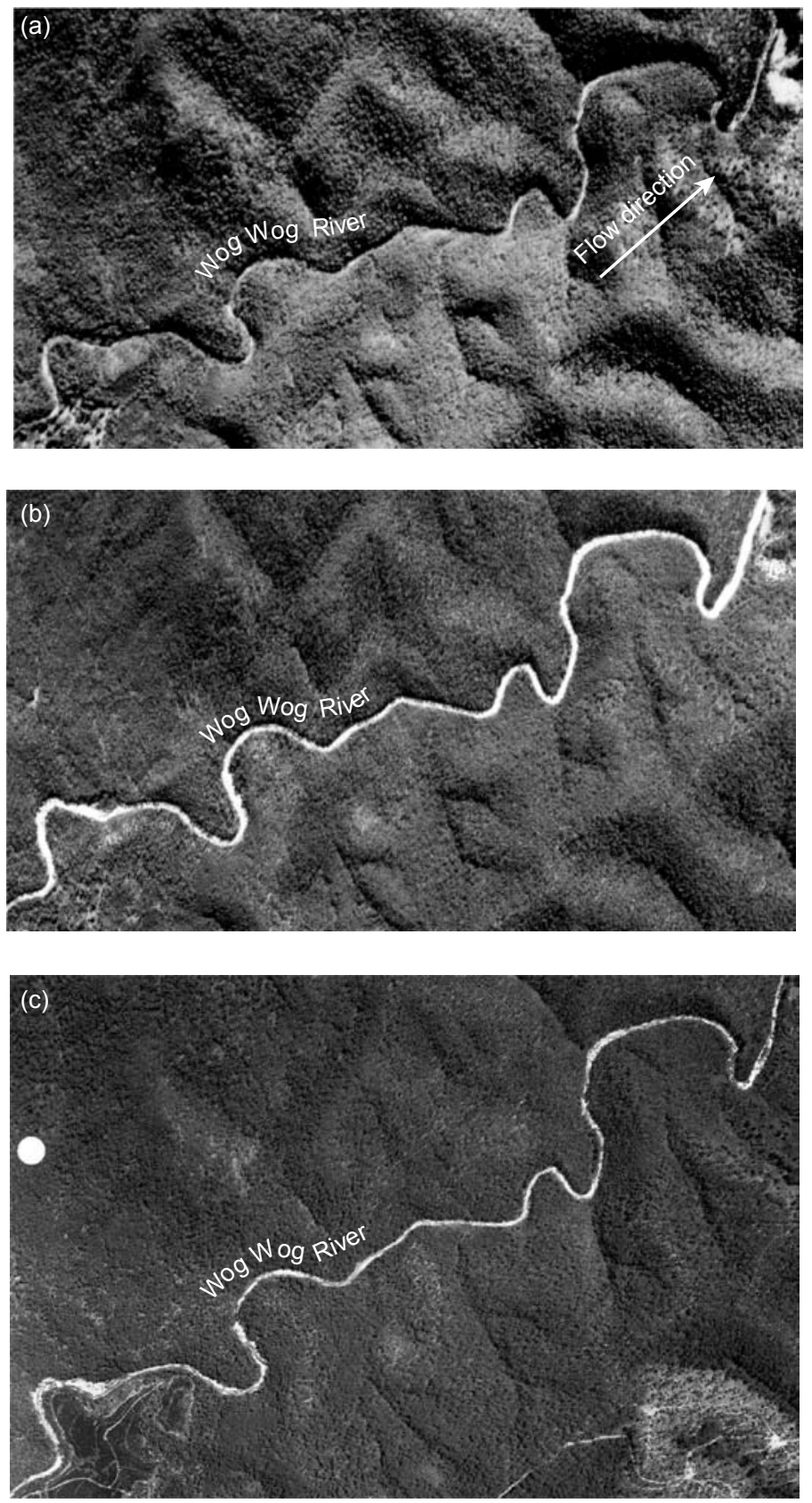

Figure 7. Vertical air photographs of Wog Wog River upstream of Letts Creek in (a) July 1962, (b) March 1971 and (c) November 1993. Note channel widening after the February 1971 flood and partial channel recovery by November 1993.

\section{Effects of integrated logging in Cpt 588/2 on soil erosion and sand and fine gravel supply to channels}

The main track used to haul timber was mainly located along the ridge between the two channels (Fig. 2). While the excavation for some rollover cross banks was occasionally too deep and hence exposed unstable subsoils, there was no connection of track runoff to either channel. This ridgetop track did not supply sand and gravel to Letts Creek or the tributary. Sand did reach some drainage lines, especially the one to the immediate north of $\log$ dump E (Fig. 2), but there was no direct connection to streams.
Mesh fences stored large amounts of sediment that were eroded from the feeder road before it was revegetated. This material did not reach the sedimentation pond let alone the drainage lines further down slope. The sedimentation pond (Fig. 3) contains two sediment types, a mud unit and a coarse delta unit. The pond mud fines upwards from muddy fine sand to fine sandy clay (texture classes of Folk (1980)) and was formed by still-water settling of suspended sediment (Fig. 5) supplied by road drainage. About $2.5 \mathrm{~m}^{3}$ of mud are trapped in the pond. There are three lobes of coarse sediment which consists of up to $0.4 \mathrm{~m}$ of sandy granule gravel. About $4.3 \mathrm{~m}^{3}$ of fine gravel and sand have been deposited in the delta. Figure 5 demonstrates that the pond delta is similar to the overpassing sand and fine gravel in Letts Creek and the tributary. However, none of this sediment has passed through the sedimentation pond since 3 June 1992. There is also no evidence of erosion of the spillway channel from the pond by spills.

Although logged slopes looked bare of ground cover, the soil surface had very high roughness. Ground disturbance was extensive and much woody debris was left on the soil surface. There had been substantial soil redistribution but the eroded material had not been transported far, except in the vicinity of the feeder road. Over most of Cpt 588/2 sediment did not leave the logged slopes. However, there must be erosion of silt and clay after logging to account for the increased suspended sediment yields measured in the nearby Yambulla experimental catchments by Rieger et al. (1979) and Olive and Rieger (1987, 1988). This suspended sediment, however, does not contribute to downstream sand and gravel deposition. Olley et al. (1996) found that soil movement was occurring on slopes following logging but detailed radionuclide measurements demonstrated that minor amounts of sand were reaching the channel. Instead the sediment in channels was derived mainly from in-channel sources, such as bank erosion (Olley et al. 1996).

The Chief Executive of Forests NSW had the allegations of erosion in Cpt 588/2 due to logging and the consequent supply of sand and fine gravel to the channels investigated independently by the internal audit unit. The outcome was reported to critics on 3 June 1992 as:

There is evidence of recent movement of fresh sand along a drainage line following heavy rain in mid-February. This emanated from an area where soil conservation works were subsequently implemented. However, evidence of recent deposition of sand stops well short of Letts Creek.

The drainage line is the one north of log dump $\mathrm{E}$ in Figure 2.

\section{Discussion and conclusions}

Increased sediment yields from harvested compartments and or forest roads can affect channels further down slope, but only where best management practices have not been followed (Megahan 1972). Roads are usually the most significant sediment source in Australian timber production forests (Croke et al. 1997, 1999c, 2001; Wallbrink and Croke 2002). Rainfall simulator experiments in integrated logged areas near Eden found that unsealed forest roads generated one order of magnitude more sediment than recently disturbed snig tracks, which generated one order of magnitude more sediment than the adjacent general harvest area (Croke et al. 1999c, 2001; Wallbrink and Croke 2002). The rapid 
exhaustion of the sediment supplies, however, limited the amount of material available for mobilisation from all sources (Croke et al. 1999 c). Soil erosion on snig tracks declined greatly with time since disturbance, with about 5 y required for recovery (Croke et al. 1999c, 2001). Therefore, effective sediment control measures are needed during and immediately after disturbance to reduce off-site impacts (Croke et al. 1999c, 2001) and such measures were included in Anon. $(1985,1990)$ which applied at the time of harvesting in Cpt 588/2. Furthermore, the extensive soil conservation works implemented immediately after the February 1992 storm in Cpt 588/2 targeted the most-disturbed areas and increased sediment storage within the general harvest area.

While roads and snig tracks are significant sources of runoff and sediment, the general harvest area is an important dispersal area, minimising the transfer of water and sediment from harvested areas to streams (Croke et al. 1999a,b,c; Lacey 2000; Wallbrink et al. 2002; Wallbrink and Croke 2002). A flow path $5 \mathrm{~m}$ long was sufficient to deposit over $50 \%$ of the fine-grained sediment at Eden (Croke et al. 1999c; Wallbrink and Croke 2002). Lacey (2000) found sediment trap efficiencies of over $90 \%$ for undisturbed flow paths $10 \mathrm{~m}$ long. Filter strips were at least $20 \mathrm{~m}$ wide in $\mathrm{Cpt}$ $588 / 2$ and are particularly effective in trapping sand, which is deposited when the velocity of overland flow is locally reduced (Loch et al. 1999). Intense large storms, however, can generate sufficient overland flow to break through buffers and filters to streams (Hairsine et al. 2002). While the February 1992 storm did generate sufficient overland flow on roads and tracks to break through buffers to drainage lines, floodouts trapped sand and fine gravel which reached the discontinuous gully on the tributary. There was no evidence of sand and fine gravel being supplied further down-slope to streams.

Wallbrink et al. (1997, 2002), Wallbrink and Croke (2002) and Croke et al. (1999c) measured soil erosion and sediment redistribution $5 \mathrm{y}$ after integrated logging using radionuclides in a small basin within a single compartment in the nearby upper Genoa basin NSW. They used the tracers ${ }^{137} \mathrm{Cs}$ and ${ }^{210} \mathrm{~Pb}_{\mathrm{ex}}$ to construct sediment budgets. There was no net soil loss from the compartment within the uncertainties of the technique. Significant sediment redistribution, storage and transport occurred, as found elsewhere (Mackay et al. 1985; Burgess 1987; Erskine 1992; Saynor et al. (1994). Wallbrink et al. (2002) found net soil loss from snig tracks and log landings, and that this eroded material was trapped in down-slope cross-banks, the general harvest area and filter strips. Coarse sediment was trapped upslope of the filter strips and fine sediment was retained in the filter strips. Significant sediment redistribution within the general harvest area certainly occurred in Cpt 588/2 during the February 1992 storm. This does not automatically mean, however, that sediment was supplied directly to down-slope channels (Burgess 1987; Erskine 1992).

Current forest management practices aim to transfer water and sediment from disturbed forest areas (tracks, roads and log dumps) to less disturbed parts of the forest, increasing sediment storage on hillslopes (Croke et al. 1999c; Lacey 2000; Wallbrink and Croke 2002). This was also the aim in 1992 although there were problems with the feeder road. The soil conservation works successfully stabilised the disturbed areas and the sedimentation pond prevented any sand and fine gravel from reaching the drainage line further down slope. Gully initiation at road drainage outlets should be minimised to reduce any road-to-stream connections and to avoid increasing drainage density (Croke and Mockler 2001). Receiving area slope and contributing road area are the most significant factors determining gully initiation at road drainage structures (Croke and Mockler 2001). No such gullies were recorded on the feeder road and the soil conservation work prevented the subsequent development of gullies. Road-to-stream connection did not occur during or after the February 1992 storm in Cpt 588/2.

The large flood variability characteristic of Australian rivers means that catastrophic floods occur more frequently on these rivers than elsewhere (Erskine 1996; Erskine and Saynor 1996). The high stream power generated by catastrophic floods produces large-scale channel erosion and deposition (Erskine 1993, 1996; Erskine and Saynor 1996; Thomson et al. 2006, 2008). Channel erosion is the dominant sediment source on rivers with high flood variability (Erskine 1996; Erskine and Saynor 1996; Erskine and Warner 1999) and the Towamba catchment is no exception. The lack of continuous sand and fine gravel, and the presence of marked sediment discontinuities (filter strips, floodouts, sedimentation pond) between the general harvest area and the high-energy reaches on Letts Creek and its tributary indicate that the general harvest area was not a source of sand and fine gravel for Letts Creek. Bank erosion in the high-energy reaches of Letts Creek and its tributary supplied the sand and fine gravel that infilled pools and overpassed the boulders forming the bed framework.

Although an intense storm on 11 February 1992 caused severe erosion of a feeder road in Cpt 588/2 there was no evidence of sand and fine gravel being supplied further down-slope to streams. The eroded sand and fine gravel was stored down-slope in the general harvest area, filter strips and floodouts and not supplied to channels. Soil conservation works stabilised the severely eroded areas. Catastrophic floods and large flood clusters (successions of large floods in a short time) caused substantial bank erosion but preceded integrated logging in Cpt 588/2. Bank erosion supplied the sand and fine gravel stored in pools by preferential removal of silt and clay in suspension. Bank erosion can supply most of the coarse sediment transported by rivers, as shown by sediment budgets (Erskine and Saynor 1996; Erskine and Warner 1999) and sediment tracers (Olley et al. 1996; Wallbrink et al. 1997, 2002; Croke et al. 1999c; Wallbrink and Croke 2002). Integrated logging, erosion and sedimentation are not dirty words, provided best management practices are implemented as part of harvesting and subsequent site rehabilitation (Megahan 1972; Croke et al. 1999c; Wallbrink and Croke 2002).

\section{Acknowledgements}

Charlie Bell, Bryan Clark, Julia Clark, Marty Linehan, Bob Bridges, Lisa Turner, Paul Corbett, Mike Bullen and Steve Dodds assisted this work. Forests NSW permitted access to their files and records. Drs A. Chalmers, J. Sammut, M. Saynor, A. Keene and L. Turner commented on an earlier version of the paper. 


\section{References}

Anon. (1968) Water Resources of the Towamba and Genoa Valleys. Water Conservation and Irrigation Commission, Sydney.

Anon. (1976) Floods of February 1971 on the South Coast. Water Resources Commission of NSW, North Sydney.

Anon. (1985) Erosion mitigation conditions for logging in Eden Forestry Region. Forestry Commission of NSW, Sydney.

Anon. (1989) Forest Types in New South Wales. Forestry Commission of New South Wales Research Note No. 17.

Anon. (1990) Code of Logging Practice, Native Forest Areas, Eden, Bombala and Bega Districts. Forestry Commission of NSW, Sydney.

Bishop, A.V. (1973) Flood rains and erosion in the Bega Valley - 1971. Journal of Soil Conservation Service of NSW 29(1), 22-28.

Burgess, J. (1987) Recent sedimentation in the Wonboyn River system. In: Conacher, A. (ed.) Readings in Australian Geography. Institute of Australian Geographers (WA Branch) and Department of Geography, University of Western Australia, Perth, pp. 413-419.

Croke, J. and Mockler, S. (2001) Gully initiation and road-to-stream linkage in a forested catchment, southeastern Australia. Earth Surface Processes and Landforms 26, 205-217.

Croke, J., Hairsine, P., Fogarty, P., Mockler, S. and Brophy, J. (1997) Surface runoff and sediment movement on logged hillslopes in the Eden Management Area of south eastern NSW. Cooperative Research Centre for Catchment Hydrology Report 97/2. Clayton, Victoria.

Croke, J., Hairsine, P. and Fogarty, P. (1999a) Sediment transport, redistribution and storage on logged forest hillslopes in southeastern Australia. Hydrological Processes 13, 2705-2720.

Croke, J., Hairsine, P. and Fogarty, P. (1999b) Runoff generation and redistribution in logged Eucalyptus forests, south-eastern Australia. Journal of Hydrology 216, 56-77.

Croke, J., Wallbrink, P., Fogarty, P., Hairsine, P., Mockler, S., McCormack, R. and Brophy, J. (1999c) Managing sediment sources and movement in forests: the forest industry and water quality. Cooperative Research Centre for Catchment Industry Report 99/11. Clayton, Victoria.

Croke, J., Hairsine, P. and Fogarty, P. (2001) Soil recovery from track construction and harvesting changes in surface infiltration, erosion and delivery rates with time. Forest Ecology and Management 143, 3-12.

Erskine, W.D. (1992) An Investigation of Sediment Sources in the Genoa River Catchment. East Gippsland River Management Board, Mallacoota, Victoria, $88 \mathrm{pp}$.

Erskine, W.D. (1993) Erosion and deposition produced by a catastrophic flood on the Genoa River, Victoria. Australian Journal of Soil and Water Conservation 6(4), 35-43.

Erskine, W.D. (1996) Response and recovery of a sand-bed stream to a catastrophic flood. Zeitschrift fur Geomorphologie 40, 359-383.

Erskine, W.D. (1999) Oscillatory response versus progressive degradation of incised channels in southeastern Australia. In: Darby, S.E. and Simon, A. (eds) Incised River Channels: Processes, Forms, Engineering and Management. Wiley, Chichester, pp. 67-95.

Erskine, W.D. and Harris, J.H. (2004) Australia. In: Northcote, T.G. and Hartman, G.F. (eds) Fishes and Forestry. Worldwide Watershed Interactions and Management. Blackwell Science, Oxford, pp. 678-703.

Erskine, W.D. and Saynor, M.J. (1996) Effects of catastrophic floods on sediment yields in southeastern Australia. In: Walling, D.E. and Webb, B.W. (eds) Erosion and Sediment Yield: Global and Regional Perspectives. International Association of Hydrological Sciences, Wallingford, pp. 381-388.
Erskine, W.D. and Warner, R.F. (1999) Significance of river bank erosion as a sediment source in the alternating flood regimes of southeastern Australia. In: Brown, A. and Quine, T. (eds) Fluvial Geomorphology and Environmental Change. Wiley, Chichester, pp. 139-163.

Folk, R.L. (1980) Petrology of Sedimentary Rocks. Hemphill, Austin, USA.

Grant, G.E., Swanson, F.J. and Wolman, M.G. (1990) Pattern and origin of stepped-bed morphology in high gradient streams, Western Cascades, Oregon. Geological Society of America Bulletin 102, 340-352.

Hairsine, P.B., Croke, J.C., Mathews, H., Fogarty, P. and Mockler, S.P. (2002) Modelling plumes of overland flow from roads and logging tracks. Hydrological Processes 16, 2311-2327.

Henry, H.M. (1977) Catastrophic channel changes in the MacDonald Valley, New South Wales, 1949-1955. Journal and Proceedings of the Royal Society of NSW 110, 1-16.

Keller, E.A. (1971) Areal sorting of bed-load material: the hypothesis of velocity reversal. Geological Society of America Bulletin 82, $753-756$.

Lacey, S.T. (2000) Runoff and sediment attenuation by undisturbed and lightly disturbed forest buffers. Water, Air, and Soil Pollution 122, 121-138.

Lewis, P.C. and Glen, R.A. (1995) Bega-Mallacoota 1:250000 Geological Sheet, SJ/55-4, SJ55-8. 2nd edn. Geological Survey of NSW, Sydney.

Lewis, P.C., Glen, R.A., Pratt, G.W. and Clarke, I. (1995) Bega-Mallacoota 1: 250000 Geological Sheet, SJ55-4, SJ55-8: Explanatory Notes. Geological Survey of NSW, Sydney, 148 pp.

Lisle, T.E. (1979) A sorting mechanism for a riffle pool sequence: summary. Geological Society of America Bulletin 90 (Pt II), 616-617.

Loch, R.J., Espigares, T., Costantini, A., Garthe, R. and Bubb, K. (1999) Vegetative filter strips to control sediment movement in forest plantations: validation of a simple model using field data. Australian Journal of Soil Research 37, 929-946.

Mackay, S.M., Long, A.C. and Chalmers, R.W. (1985) Erosion pin estimates of soil movement after intensive logging and wildfire. In: Loughran, R.J. (ed.) Drainage Basin Erosion and Sedimentation, Conference and Review Papers. Volume 2. University of Newcastle, Newcastle, pp. 15-22.

Megahan, W.F. (1972) Logging, erosion, sedimentation — are they dirty words? Journal of Forestry 70, 403-407.

Melville, M.D. and Erskine, W.D. (1986) Sediment remobilization and storage by discontinuous gullying in humid southeastern Australia. In: Hadley, R.F. (ed.) Drainage Basin Sediment Delivery. International Association of Hydrological Sciences, Wallingford, pp. 277-286.

Neil, D.T. and Fogarty, P. (1991) Land use and sediment yield on the Southern Tablelands of New South Wales. Australian Journal of Soil and Water Conservation 4(2), 33-39.

Newson, M. (1980) The geomorphological effectiveness of floods - a contribution stimulated by two recent events in mid-Wales. Earth Surface Processes 5, 1-16.

Olive, L.J. and Rieger, W.A. (1987) Eden Catchment Project: Sediment Transport and Catchment Disturbance 1977-1983. Department of Geography and Oceanography, Australian Defence Force Academy, Monograph Series No. 1, Canberra, 162 pp.

Olive, L.J. and Rieger, W.A. (1988) Problems in assessing the impact of different forestry practices on coastal catchments in New South Wales. In: Warner, R.F. (ed.) Fluvial Geomorphology of Australia. Academic Press, Sydney, pp. 283-302. 
Olley, J.M., Murray, A.S. and Wallbrink, P.J. (1996) Identifying sediment sources in a partially logged catchment using natural and anthropogenic radioactivity. Zeitschrift fur Geomorphologie Suppl. Bd. 105, 111-127.

Peterson, J.T. and Rabeni, C.F. (2001a) Evaluating the physical characteristics of channel units in an Ozark stream. Transactions of the American Fish Society 130, 898-910.

Peterson, J.T. and Rabeni, C.F. (2001b) The relation of fish assemblages to channel units in an Ozark stream. Transactions of the American Fish Society 130, 911-926.

Pilgrim, D.H. and Doran, D.G. (1987) Flood frequency analysis. In: Pilgrim, D.H. (ed.) Australian Rainfall and Runoff. Volume 1. Institution of Engineers Australia, Barton, pp. 195-236.

Prosser, I.P. and Soufi, M. (1998) Controls on gully formation following forest clearing in a humid temperate environment. Water Resources Research 34, 3661-3671.

Rieger, W.A., Olive, L.J. and Burgess, J.S. (1979) Sediment discharge response to clear-fell logging in selected small catchments, Eden, NSW. Proceedings 10th New Zealand Geography Conference, Auckland, pp. 44-48.

Routley, R. and Routley, V. (1975) The Fight for the Forests: The Takeover of Australian Forests for Pines, Wood Chips and Intensive Forestry. Research School of Social Sciences, Australian National University, Canberra.
Saynor, M.J., Loughran, R.J., Erskine, W.D. and Scott, P.F. (1994) Sediment movement on hillslopes measured by caesium-137 and erosion pins. In: Olive, L.J., Loughran, R.J. and Kesby, J.A. (eds) Variability in Stream Erosion and Sediment Transport. International Association of Hydrological Sciences, Wallingford, pp. 87-93.

Thompson, C.J., Croke, J., Ogden, R. and Wallbrink, P. (2006) A morpho-statistical classification of mountain stream reach types in southeastern Australia. Geomorphology 81, 43-65.

Thompson, C., Croke, J. and Takken, I. (2008) A catchment scale model of mountain stream channel morphologies in southeast Australia. Geomorphology 95, 119-144.

Wallbrink, P.J. and Croke, J. (2002) A combined rainfall simulator and tracer approach to assess the role of best management practices in minimising sediment redistribution and loss in forests after harvesting. Forest Ecology and Management 170, 217-232.

Wallbrink, P.J., Roddy, B.P. and Olley, J.M. (1997) Quantifying the Redistribution of Soils and Sediments Within a Post-Harvested Forest Coupe near Bombala, New South Wales, Australia. CSIRO Land and Water Technical Report No. 7/97.

Wallbrink, P.J., Roddy, B.P. and Olley, J.M. (2002) A tracer budget quantifying soil redistribution on hillslopes after forest harvesting. Catena 47, 179-201.

Wolman, M.G. (1977) Changing needs and opportunities in the sediment field. Water Resources Research 13, 50-54. 